\title{
Gender-linked differences in graduate L2 learners' speech acts in the university setting
}

\author{
Rahimi Domakani, Masoud \\ Shahrekord University, Iran (rahimi@lit.sku.ac.ir) \\ Farhang-Ju, Maryam $\bowtie$ \\ Shahrekord University, Iran (Farhang.mariam@gmail.com)
}

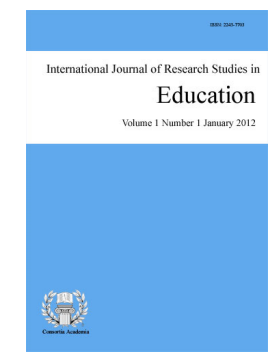

ISSN: 2243-7703 Online ISSN: 2243-7711

OPEN ACCESS

\section{Abstract}

Detailed analyses of second language (L2) learners' requests may provide more insight into the nature of L2 in use in university setting. Such requests may include different discursive moves for different genders. This trend seems rewarding due to changes caused by the advent of feminism in discourse communities of developing countries like Iran in recent years. Despite the preponderance of cross-cultural and developmental studies that investigated L2 requests, few systematic attempts have been made to describe the distribution and nature of request discursive moves across genders in university setting. By the detailed analyses of their requests, the present study embarked on determining gender-linked differences in graduate male and female L2 learners' requests. To this aim, 121 graduate L2 learners - 57 males and 64 females - in different Iranian State Universities, were selected based on convenient sampling to participate in this study. Request data were collected by means of a discourse completion test (DCT). Requests, then, were coded and analyzed quantitatively and qualitatively. Frequency and chi-square test were performed for each situation. Findings indicated the majority of male and female participants relied on negative polite strategy and speaker-hearer oriented perspectives for initiating their requests. Analyses of internal and external modifiers further indicated these modifiers were combined in the male and female participants' requests. In conclusion, findings indicated that there were no significant differences between the male and female participants. This study has implications for L2 teachers and learners and course designers.

Keywords: external modifiers; gender; internal modifiers, negative polite strategy; requests 


\section{Gender-linked differences in graduate L2 learners' speech acts in the university setting}

\section{Introduction}

The notion of speech acts was developed and defined by Searle (1969) as a set of utterances by which people perform a specific function such as apologizing, complaining, requesting, refusing, and complimenting. Speech acts are realized (in)directly; however, they are mainly performed indirectly to intensify the illocutionary force of requests. As for the indirect speech acts, the L2 forms do not explicitly represent the speakers' actual intention. Hence, for understanding the speakers' actual intention, addressee has to consider the meaning of the utterance in a particular context and infer the intended meaning. Further, addressee should know the appropriate practices of speech acts (LoCastro, 2012). This simply means that L2 learners should have pragmatic knowledge.

According to Leech (2016), pragmatic knowledge includes functional (pragmalinguistics) and Sociopragmatic knowledge. Functional knowledge represents the knowledge of using L2 forms to realize pragmatic functions, such as using I am wondering if when requesting, whereas sociolinguistic knowledge is the knowledge of using L2 forms appropriately according to different situational variables (e.g., social status, familiarity, power relationship, and degree of imposition), such as choosing polite forms when communicating with people of higher social status (Kasper \& Rose, 2002). In order to be identified as a polite member of a discourse community, L2 learners are required to draw on their pragmatic knowledge.

In this respect, to make appropriate choices in interaction, L2 learners should be aware of the fact that certain pragmatic devices (e.g., hedges) and sociopragmatic strategies (e.g., indirect directives) are indicators of femininity, whereas others (e.g., direct directives, swear words) indicate masculinity. Equally important is awareness that the appropriate ways of speaking for males and females in different contexts (e.g., university) so that they can conform to them (King \& Holmes, 2014). Therefore, it may be claimed that individuals of different genders tend to bring along their identity in communication within discourse communities.

Moreover, as highlighted by van Dijk, Ting Toomy, Smitherman, and Troutman (1997), the social and cultural trends of human societies are realized in language, discourse, and communication, and each community may have its norms, values, and ways of communication. Thus, the academic discourse community can be said to have a high level of (non)linguistic sophistication. Inevitably, then, the members of this community should manifest more or less similar patterns of behavior in order to sustain their membership. However, the realization of speech patterns of the member of this community requires rigorous analyses on the part of L2 researchers and is not easily achieved. Thus, there is a need to attend to them.

Further, it seems, with the advent and rapid growth of communication via the computer terminal, there have been changes in style and grammatical features of language used in face-to-face interaction, and gender differences may be here, as well. Although the role of gender in L2 pragmatic performance has been studied in Iranian EFL context (e.g., Memari, Zia, \& Zalpour, 2017; Pishghadam \& Sharafadini, 2011), few studies have probed the patterns of gendered use of request. Considering this and the variable nature of face-to-face interaction, by the detailed analyses of their requests, the present study embarked on determining gender-linked differences in graduate male and female L2 learners' requests in university setting.

\section{Literature review}

\subsection{Components of request}

Requests, as the mostly employed speech acts in daily communication, may threaten the addressee's negative face. The fact that requests are face-threatening may stem from two issues. First, the illocutionary force 
of requests is to ask someone to do something or refrain them from doing something. Therefore, it may interfere with the addressee's freedom of action. Second, the addressee may choose to decline the request (Brown \& Levinson, 1987). Considering this, requests are considered to threat the speakers' face. Thus, speakers should use appropriate polite strategies by considering many factors when requesting.

The selection of speakers' politeness strategies can affect the linguistic devices for expressing requests. Blum-Kulka, House, and Kasper (1989) examined these linguistic means as a part of the cross-cultural speech act realization project (CCSARP). Based on the CCSARP, requests consist of alerters, head acts, and supportive moves. A head act is considered the core of the request. The CCSARP documented nine distinct strategy types for variation in the (in)directness levels of head act: mood derivable (e.g., Close the window), explicit performative (e.g., I am asking you to close the window.), hedged performative (e.g., I have to ask you to close the window), locution derivable (e.g., You have to close the window), want statement (I'd like you to close the window), suggestory formula (e.g., How about closing the window?), query preparatory (e.g., I was wondering if you would close the window), and strong hint (e.g., The window is open), mild hint (e.g., It is very cold in here).

In addition to classifying requests by (in)directness, the CCSARP also identified four perspectives among requests: hearer-oriented (e.g., Can you do it?), speaker-oriented (e.g., Can I have it?), inclusive, in which both hearer and speaker are mentioned (e.g., Can we close the window?), and impersonal, when neither speaker nor hearer is included (e.g., The window needs to be closed).

Based on the CCSARP, alerters, which are the opening elements preceding the actual requests, consist of address terms (e.g., dear) and/or attention-getters (e.g., hi). The other elements of requests are internal and external modifiers. Internal modifiers act as downgrades (i.e., syntactic and lexical downgraders) to make requests less forceful. The CCSARP coding manual identifies seven types of syntactic downgraders used to intensify the illocutionary force of requests: interrogative (e.g., Can you close the window?), negation of a preparatory condition (e.g., You couldn't close the window, could you?), subjunctive (e.g., It might be better if you were to close the window now), conditional (e.g., Would you close the window?), aspect (e.g., I am wondering if you can close the window), past tense (e.g., I wanted to ask you if you could close the window), conditional clause (e.g., It would be so nice if you could close the window).

Further, lexical downgraders are distinguished into seven types: politeness markers (e.g. Please, close the window), play-downs (e.g., I wondered if ), consultative devices (e.g., Would you mind), Hedges (e.g., kind of ), understaters (e.g., a bit), downtoners (e.g., possibly), committers (e.g., I think), forewarning, (e.g., far be it from me to criticize, but ...), hesitators (e.g., er, uh, ah), scope-starters (e.g., I'm disappointed that you couldn't ....), agent avoiders (e.g., people don't do X).

The supportive moves are another part of requests that modify head act externally. The CCSARP coding manual identified six mitigating supportive moves: grounder (e.g., Can you close the window? I got very tired at work today), imposition (e.g., Can you please close the window, but only if you are planning to go outside), preparatory (e.g., Please close the window if you are not busy), promise of reward (e.g. I would really appreciate it if you could close the window. I'll give you a thousand thanks), disarmer (e.g., I know it probably doesn't feel too cold in the room, but may I ask you to close the window?), getting a precommitment (e.g., Can I ask you a big favor? I terribly cold, and I would really appreciate if you closed the window).

In the present study, based on the CCSARP manual (Blum-Kulka et al., 1989), the aforementioned parts of requests (alerters, head act, internal and external modifiers) were examined.

\subsection{Gender}

Research on gendered L2 pragmatic patterns has made a valuable contribution to L2 learning. Evidently, being aware of gender norms is beneficial for L2 teachers and learners. Evidence to support the notion that individuals tend to show their gender while communicating comes from studies that examined L2 features in 
interaction (Herring, 2000, 2003; Janssen \& Murachver, 2004). For example, Herring (2000) declared that it is more typical for females to thank, appreciate, apologize, and include politeness markers in their speech (Rubin \& Greene, 1992; Speer, 2002). A number of studies have found that compliments and polite and appreciative language feature prominently in female speakers' speech (Herring, 2000, 2003; Janssen \& Murachver, 2004). On the other hand, the males were found to use more direct forms of speech (Mulac, Bradac, \& Gibbons, 2001; Pishghadam \& Sharafadini, 2011; Saito, 2010) and less polite language (Herring, 2000, 2003, Hobbs; 2003).

Of the other characteristics of the females' language is that they include more hedges (Memari et al., 2017; Mulac, Studley, \& Blau, 1990), intensifiers, third-person pronouns (Colley \& Todd, 2002; Janssen \& Murachver, 2004, Memari et al., 2017) than males in their writing. However, males tend to use references to quantity (Mulac \& Lundell, 1994), illustrative (Janssen \& Murachver, 2004; Rubin \& Greene, 1992), and focus adverbs (Janssen \& Murachver, 2004).

On the one hand, theories on gender and language suggest that females use females use passive language, indicating shyness and lower self-confidence (McConnell-Ginet \& Eckert, 2003). On the other hand, in the study of Huffaker and Calvert (2005), the males did use a language that was more active, inflexible, and resolute, which supports the Herring's findings (Herring, 2000, 2003). The females, however, did not use passive, cooperative, or accommodating language as the McConnell-Ginet and Eckert' (2003) study suggested. Based on the recent findings (Allami, 2006; Saidi \& Khosravi, 2015; Shams \& Afghari, 2011), one possible explanation is that language and social interaction are changing, perhaps because females are changing. This may suggest that females may have different gender roles from those of earlier generations. Alternately, females may use different L2 patterns different from older generations.

Detailed analyses of L2 learners' requests may provide more insight into the nature of L2 in use. Such requests tend to include different discursive moves for different genders. This trend seems rewarding due to changes caused by the advent of feminism in discourse communities of developing countries like Iran in recent years. Despite the preponderance of cross-cultural and developmental studies that tried to investigate L2 requests (e.g., Biesenbach-Lucas, 2007; Eslami, Mirzaei, \& Dini, 2015; Jalilifar, 2009; Hashemian, 2014), few systematic attempts were made to describe the distribution and the nature of EFL requests across genders in university setting. By the detailed analyses of male and female L2 learners' requests, the present study embarked on determining gender-linked differences in graduate male and female L2 learners' requests. To this aim, the following research questions were addressed:

1. Do request strategies and request perspectives of graduate male and female L2 learners significantly differ?

2. What are the patterns of alerters and internal and external modifiers in graduate male and female L2 learners' requests?

\section{Method}

\subsection{Participants}

To collect the data, an invitation was sent to over 200 Iranian MA students via social media applications such as e-mail and LinkedIn. A convenient sample of 137 L2 learners participated in the current study; however, 16 L2 learners were excluded from the study because their L1 was other than Persian. Researchers chose such learners because they had access to them. That is, the criterion for participation in the study was to be a native speaker of Persian. Therefore, 121 (57 male and 64 female) TEFL graduate L2 learners state universities were selected based on convenience sampling to participate in this study. The participants were native speakers of Persian and belonged to the same racial group (i.e., Persian). Their ages ranged from 23 to 41 ( $M=27.81 ; S D=$ 2.7), but the majority were in their twenties.

4 Consortia Academia Publishing (A partner of Network of Professional Researchers and Educators) 
They all were studying TEFL at different state universities. They had been determined to be relatively proficient as a result of the MA National Entrance Exam which is one of the most important high-stakes tests in Iran. The MA National Entrance Exam is designed to assess the knowledge of students who are planning to undertake their graduate studies. This exam assesses grammar, vocabulary, and reading. The use of such tests for determining the proficiency levels of L2 learners helps enhance the generalizability of research as the content of standardized tests is available for public scrutiny and their validity is subject to ongoing investigation (e.g., Roohani, Dayeri, \& Farhang-Ju, 2017). Furthermore, in university, the participants had taken English skill courses including grammar, listening, oral English, extensive reading, and writing for years. Thus, the participants were considered to be highly proficient L2 learners.

One EFL instructor participated in this study to code the requests. She was a Ph.D. candidate in one of the State Universities in Iran. She was an advanced English speaker, with more than five years of experience of teaching at different levels of language proficiency in EFL contexts. Therefore, she was considered a skillful and an experienced teacher. Furthermore, an experienced British native speaker teacher was invited to check the reliability of scoring procedure. He had an M.A. in Linguistics and was teaching English in different language schools in ESL contexts.

\subsection{Instruments}

Prior to taking part in the study, a demographic form was utilized to seek demographic characteristics like gender, age, race, and first language (L1). Also, personal experiences were surveyed with the following questions: Have you ever traveled to a foreign country? Have you ever lived in a foreign country?

Moreover, a discourse competition test (DCT) was employed to document the participants' responses in request situations. DCT provides a valid and reliable tool for research on the pragmatic knowledge of L2 learners (Kasper \& Rose 2002; Rose, 2009). To overcome its limitations, the DCT adopted an open-ended design with no hearer response, aiming to elicit more elaboration typical in natural data compared with content-poor prompts (see Lin, Woodfield, \& Ren, 2012). DCT makes it possible to gather a large sample of participants easily and to control variables which constrain the contexts. In addition, Rose (2009) argued that "asking whether an instrument (or procedure) is valid is not enough-the question is whether an instrument is valid for what purpose" (p. 2347). The choice of research instrument should be in line with the research purpose itself, and in this regard, the DCT "does provide information regarding respondents' knowledge and attitudes regarding the use of English requests" (p. 2347). Hence, DCT is especially an effective instrument to compare speech acts strategies from different languages (Blum-Kulka, 1989). The validity of the instrument was ensured by asking experts (two professors of ELT whose research interest was pragmatics). Reliability was ensured via intercoder reliability, found to be $96 \%$. The raters' reliability was measured through the agreement between the raters.

\subsection{Procedure}

The study consisted of four parts. In the first part, an email containing the purpose of the study was sent to over 300 graduate L2 learners. The researcher introduced herself, and informed the participants about the purpose of the study. The participants were also informed that the data would be used for research purposes only, and they had the right to know the results of the study. Then, 121 graduate L2 learners joined the study.

In the second part of the study, the participants were asked to determine their demographic characteristics (e.g., gender, age, L1) and personal experiences (e.g., Have you ever lived in a foreign country). The information obtained from the second part of the survey showed that the participants included 57 males and 64 females aged $23-41$.

In the third part of the study, the DCT adopted from Birjandi and Rezaei (2010) was used to collect requests written by the participants. The DCT included eight different social situations. Each situation was preceded by a short description of the social situation. The participants were asked to complete the DCT, imagining themselves 
in the given situation. Social distance and social power between the interlocutors were kept constant (i.e., in situations, the participants had to address a professor in their major):

$>$ Borrowing a book from the instructor

$>$ Asking the instructor to give the PPTs files

$>$ Asking the instructor for his/her phone number

$>$ Asking the instructor to explain the ambiguous part

$>$ Asking the instructor to extend the deadline of an assignment

$>$ Asking the instructor to change the date of an exam

$>$ Asking the instructor to check their exam grade

$>$ Asking the instructor to make an appointment for consultation

In the last phase, the data were coded and analyzed. Data analysis included analysis of alerters, head acts, and supportive moves. Following Jalilifar (2009) and Hashemian (2014), the cross-cultural speech act realization project (CCSARP) developed by Blum-Kulka et al. (1989) was used (see section 2.1). The requests were coded and analyzed with regard to the level of (in)directness, alerters, and internal and external modifiers. Below is an example of the participants' requests (request situation \# 4):

\section{$>$ Extract \# 1}

- [Alerter] Excuse me, sir! I am kind of puzzled about the second part of this chapter. [supportive move] Of course i tried to read it on my own but since $i$ was not able to make it the last session due to some health conditions $i$ couldn't get it. [Head act] Would you please be kind enough to go over the key points another time? Sorry for the inconveniences.

All the data were coded by the coder twice. To ensure the reliability of the coding procedure, $20 \%$ of the collected data were randomly selected to be coded by the native speaker teacher. The DCTs were mailed to him. The detailed analyses of the DCTs were, then, sent back to the researchers. The intercoder reliability was $96 \%$. The disparities were discussed and resolved. The data were, then, analyzed using the Statistical Package for the Social Sciences (SPSS), version 22.00. The frequency analyses were performed to determine the existing differences between the two groups. Moreover, the chi-square test for independence was run to see if there was any relationship between gender and selection of request strategies and perspectives' L2 learners. The chi-square test is used with nominal data in the form of frequency counts rather than scores (Pallant, 2013). Thus, it was suitable for the current study.

\subsection{Data analysis}

To address the research questions, a number of statistical analyses were performed. First, frequencies of each category were calculated. Then, the chi-square was run.

\section{Results and discussion}

To determine the potential differences between the participants' requests, the data elicited through the DCT were analyzed. To answer the first research question, first, the frequency request strategies and perspectives were calculated. Then, two chi-squares were employed. A strong distribution of negative polite strategies (i.e., conventionally indirect strategies) was found in the male and female participants' requests. Although the conventionally indirect strategies were the most employed request strategy type $(80.48 \%)$ by the male participants, it occurred in a higher percentage in the requests performed by the female participants $(83.99 \%)$. Finally, the distribution of direct and non-conventionally indirect strategies was marginal for the male and female participants. The female participants opted to employ direct strategies (5.4) less than their male counterparts $(12.4 \%)$, and the non-conventionally indirect strategies made up 10.72 of the female participants' requests and 7.12 of the male participants' requests. The results of the chi-square test for independence (i.e., $\chi 2$ ) results indicated that there were no significant differences between the employed request strategies by the male and

6 Consortia Academia Publishing (A partner of Network of Professional Researchers and Educators) 
female participants:

Table 1

Distribution of L2 learners' request strategies

\begin{tabular}{|c|c|c|c|c|c|c|c|c|c|}
\hline Situation & Group & Borrowing & PPT & $\begin{array}{l}\text { Phone } \\
\text { number }\end{array}$ & Explanation & $\begin{array}{l}\text { Assignment } \\
\text { Extension }\end{array}$ & Date & Grade & Meeting \\
\hline \multirow[t]{2}{*}{ Mood } & $\mathrm{F}$ & $1(1.6 \%)$ & $1(.6 \%)$ & $1(1.6 \%)$ & $1(1.6 \%)$ & $0(0 \%)$ & $7(10.9 \%)$ & $2(3.1 \%)$ & $1(1.6 \%)$ \\
\hline & M & $3(5.3 \%)$ & $2(3.5 \%)$ & $1(1.8 \%)$ & $5(8.8 \%)$ & $2(3.5 \%)$ & $7(12.3 \%)$ & $8(14 \%)$ & $3(5.3 \%)$ \\
\hline Explicit & $\mathrm{F}$ & $2(3.1 \%)$ & $0(0 \%)$ & $0(0 \%)$ & $0(0 \%)$ & $0(0 \%)$ & $0(0 \%)$ & $0(0 \%)$ & $1(1.6 \%)$ \\
\hline Performative & M & $3(5.3 \%)$ & $0(0 \%)$ & $0(0 \%)$ & $1(1.8 \%)$ & $1(1.8 \%)$ & $1(1.8 \%)$ & $2(3.5 \%)$ & $2(3.5 \%)$ \\
\hline Want & $\mathrm{F}$ & $1(1.6 \%)$ & $2(3.1 \%)$ & $2(3.1 \%)$ & $1(1.6 \%)$ & $1(1.6 \%)$ & $2(3.1 \%)$ & $1(1.6 \%)$ & $1(1.6 \%)$ \\
\hline statement & M & $1(1.8 \%)$ & $1(1.8 \%)$ & $4(7 \%)$ & $3(5.3 \%)$ & $0(0 \%)$ & $3(5.3 \%)$ & $2(3.5 \%)$ & $2(3.5 \%)$ \\
\hline Query & $\mathrm{F}$ & $58(90.6 \%)$ & $58(90.6 \%)$ & $60(93.8 \%)$ & $58(90.6 \%)$ & $42(65.6 \%)$ & $45(70.3 \%)$ & $54(84.4 \%)$ & $55(85.9 \%)$ \\
\hline Preparatory & M & $50(87.7 \%)$ & $49(86 \%)$ & $52(91.2 \%)$ & $47(82.5 \%)$ & $42(73.7 \%)$ & $38(66.7 \%)$ & $41(71.9 \%)$ & $48(84.2 \%)$ \\
\hline \multirow[t]{2}{*}{ Strong hint } & $\mathrm{F}$ & $2(3.1 \%)$ & $3(4.7 \%)$ & $1(1.6 \%)$ & $4(6.2 \%)$ & $18(28.1 \%)$ & $9(14.1 \%)$ & $7(10.9 \%)$ & $5(7.8 \%)$ \\
\hline & M & $0(0 \%)$ & $5(8.8 \%)$ & $0(0 \%)$ & $1(1.8 \%)$ & $10(17.5 \%)$ & $6(10.5 \%)$ & $4(7 \%)$ & $2(3.5 \%)$ \\
\hline \multirow[t]{2}{*}{ Mild hint } & $\mathrm{F}$ & $0(0 \%)$ & $0(0 \%)$ & $0(0 \%)$ & $0(0 \%)$ & $3(4.7 \%)$ & $1(1.6 \%)$ & $0(0 \%)$ & $1(1.6 \%)$ \\
\hline & M & $0(0 \%)$ & $0(0 \%)$ & $0(0 \%)$ & $0(0 \%)$ & $2(3.5 \%)$ & $3(2.5 \%)$ & $0(0 \%)$ & $0(0 \%)$ \\
\hline$\chi^{2}$ & & .49 & .67 & .61 & .13 & .29 & .80 & .09 & .54 \\
\hline
\end{tabular}

Note. $\mathrm{F}=$ female, $\mathrm{M}=$ male.

Table 2 illustrates the distribution of the participants' request perspectives. Whereas the females preferred to make their requests hearer-oriented (55\%), speaker-oriented perspective was used in a higher percentage by the male participants $(47.7 \%)$. The other most common categories of request perspective in the male and female participants' requests were hearer-oriented $(45.6 \%)$ and speaker-oriented $(40 \%)$, respectively. The inclusive request perspective was used only in two request head acts by the males (e.g., Can we meet each other tomorrow?). The female participants did not use inclusive perspective. As for the impersonal request perspective, the magnitude for the male and female participants was marginal. The results of the chi-square test for independence indicated that there was no relationship between gender and the selection of request perspectives used by the participants except for one situation (phone number; see Table 2):

Table 2

Distribution of L2 learners' request perspectives

\begin{tabular}{|c|c|c|c|c|c|c|c|c|c|}
\hline Situation & Group & Borrowing & PPT & $\begin{array}{l}\text { Phone } \\
\text { number }\end{array}$ & Explanation & $\begin{array}{l}\text { Assignment } \\
\text { Extension }\end{array}$ & Date & Grade & Meeting \\
\hline \multirow[t]{2}{*}{ Speaker-oriented } & $\mathrm{F}$ & $29(45.3 \%)$ & $28(43.8 \%)$ & $49(76.6 \%)$ & $7(10.9 \%)$ & $49(76.6 \%)$ & $5(7.8 \%)$ & $9(14.1 \%)$ & $27(42.2 \%)$ \\
\hline & M & $30(52.63 \%)$ & $27(47.4 \%)$ & $44(77.2 \%)$ & $10(17.5 \%)$ & $50(87.7 \%)$ & $11(19.3 \%)$ & $11(19.3 \%)$ & $30(52.6 \%)$ \\
\hline \multirow[t]{2}{*}{ Hearer-oriented } & $\mathrm{F}$ & $32(50 \%)$ & $33(51.6 \%)$ & $15(23.4 \%)$ & $54(84.4 \%)$ & $11(17.2 \%)$ & $50(78.1 \%)$ & $50(78.1 \%)$ & $37(57.8 \%)$ \\
\hline & M & $26(45.6 \%)$ & $26(45.6 \%)$ & $8(14 \%)$ & $43(75.4 \%)$ & $3(5.3 \%)$ & $36(63.2 \%)$ & $40(70.2 \%)$ & $25(43.9 \%)$ \\
\hline \multirow[t]{2}{*}{ Inclusive } & $\mathrm{F}$ & $0(0 \%)$ & $0(0 \%)$ & $0(0 \%)$ & $0(0 \%)$ & $0(0 \%)$ & $0(0 \%)$ & $0(0 \%)$ & $0(0 \%)$ \\
\hline & M & $0(0 \%)$ & $0(0 \%)$ & $0(0 \%)$ & $0(0 \%)$ & $0(0 \%)$ & $0(0 \%)$ & $1(1.8 \%)$ & $1(1.8 \%)$ \\
\hline \multirow[t]{2}{*}{ impersonal } & $\mathrm{F}$ & $3(4.7 \%)$ & $3(4.7 \%)$ & $0(0 \%)$ & $3(4.7 \%)$ & $4(6.2 \%)$ & $9(14.1 \%)$ & $5(7.8 \%)$ & $0(0 \%)$ \\
\hline & M & $1(1.8 \%)$ & $4(7 \%)$ & $5(8.8 \%)$ & $4(7 \%)$ & $4(7 \%)$ & $10(17.5 \%)$ & $5(8.8 \%)$ & $1(1.8 \%)$ \\
\hline$\chi^{2}$ & & .54 & .74 & .03 & .46 & .12 & .12 & .59 & .25 \\
\hline
\end{tabular}

The detailed analyses of alerters indicated that formal address terms predominated in both groups' requests. Interestingly, the mostly employed address term found in the male participants' requests was sir, whereas professor was more frequently found in the females' requests. Further, attention-getter occurred exclusively in the form of apologies (e.g., excuse me) in the male and female participants' requests, whereas greetings (e.g., hello) occurred in a lower percentage for both groups. The results further illustrated that apology occurred more frequently in the female participants' requests (see Table 3):

Table 3

Distribution of occurrence alerters in L2 learners' requests

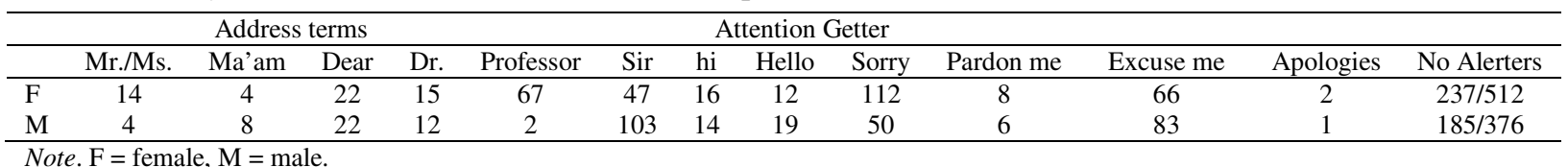


Rahimi Domakani, M., \& Farhang-Ju, M.

Next, the distribution of internal modifiers was calculated. Table 4 shows the distribution of lexical and syntactic modifiers. Of the internal modifiers that occurred across the eight situations, syntactic modifiers predominated in the male and female participants' requests. The requests of both groups were modified using two main syntactic modifiers: interrogative participants, interrogatives were the most frequently represented type of syntactic modifiers with conditional clause being the other frequently used syntactic modifier in the male and female participants' data. However, the males' requests contained a higher number of the conditional clauses than the females' requests.

Lexical modifiers were relatively frequent in the requests of both groups. Hedges and forewarn were the least frequent in both groups. As shown in Table 4, of the eight types of lexical modifiers that appeared in the data, politeness marker (please) was the most frequent means of lexical modifiers followed by Consultative device:

\section{Table 4}

Distribution of occurrence internal modifiers

\begin{tabular}{|c|c|c|c|c|}
\hline & & Group & Frequency & Example in the data \\
\hline \multirow{10}{*}{ Syntactic } & Interrogative & $\mathrm{F}$ & 393 & Can you please send a copy to me? \\
\hline & & M & 326 & \\
\hline & Past Tense & $\mathrm{F}$ & 1 & I wanted to ask if I could borrow your book for some days. \\
\hline & & M & 7 & \\
\hline & Progressive & $\mathrm{F}$ & 10 & I was wondering if I could have the power point file! \\
\hline & Aspect & M & 15 & \\
\hline & Conditional & $\mathrm{F}$ & 118 & I would be grateful if you could give me a brief explanation. \\
\hline & Clause & M & 95 & \\
\hline & Politeness & $\mathrm{F}$ & 187 & Would you please do me a favor and give me the power point file? \\
\hline & Marker (please) & $\mathrm{m}$ & 137 & \\
\hline \multirow{14}{*}{ Lexical } & Play-Down & $\mathrm{F}$ & 53 & I wondered if I might have your number in the case I need to call? \\
\hline & & M & 32 & \\
\hline & Consultative & $\mathrm{F}$ & 70 & Could you inform me of the appropriate time to meet you in your office? \\
\hline & Device & M & 114 & \\
\hline & Hedge & $\mathrm{F}$ & 0 & I would like to have your phone number if it is not kind of a big favor to ask. \\
\hline & & M & 2 & . \\
\hline & Understater & $\mathrm{F}$ & 52 & Is there the possibility that you clarify a bit regarding the issue? \\
\hline & & M & 21 & \\
\hline & Downtoner & $\mathrm{F}$ & 46 & May I ask you to kindly lend me yours? \\
\hline & & M & 42 & \\
\hline & Committer & $\mathrm{F}$ & 35 & I believe I must have got a higher score. \\
\hline & & M & 15 & \\
\hline & Forewarn & $\mathrm{F}$ & 4 & I know there's no doubt regarding your scoring, but I need to see my paper. \\
\hline & & M & 6 & \\
\hline
\end{tabular}

The rigorous analyses of request supportive moves illustrated that both male and female participants mainly used grounder to elaborate the request head act externally. The least common external modifiers used by both male and female participants were getting recommitment (see Table 5).

\section{Table 5}

Distribution of L2 learners' external modifiers

\begin{tabular}{lccl}
\hline & Group & Frequency & Example in the data \\
\hline Grounder & Female & 225 & Excuse me sir as I was absent the last session and I cannot understand some parts. May \\
& Male & 112 & I ask to give a brief explanation about these part? \\
Disarmers & Female & 10 & I know that you're not responsible but can I ask you to explain this part for me again? \\
& Male & 15 & \\
Imposition & Female & 24 & I would appreciate if u tell me about the PowerPoint file \\
Minimizer & Male & 9 & \\
Preparatory & Female & 10 & Would you please let me know if you find any time? \\
& Male & 6 & \\
Getting & Female & 8 & Could I ask you for a favor? Is there any chance I could borrow your book? \\
recommitment & Male & 6 &
\end{tabular}




\section{Discussion}

Data from the present study showed that the requests were modified by various types of internal and external modifiers. However, the analyses of the data indicated there were no significant differences between the male and female participants' requests.

Turning to request head acts, in the majority of the L2 requests in this study, the participants relied on conventionally indirect strategies to mitigate their requests. Support for the prevalence of conventionally indirect strategies in L2 requesting behavior is evident from previous cross-cultural studies (e.g., Hashemian \& Farhang-Ju, 2017; Jalilifar, 2009). For example, in their study, Hashemian and Farhang-Ju (2017) observed the prevalence of conventionally indirect strategies in intermediate L2 learners' requests. This finding reflects an appropriate level of politeness and formality expressed in the request head acts. This may imply that when L2 learners mitigate their requests to a professor, they utilize their pragmatic knowledge to choose appropriate requests in hierarchical relationships, like in a professor-student relationship where the negotiation of face is asymmetric (Scollon \& Scollon 2001).

Turning to the results, the fact the both males and females preferred to make their requests (situation \# 1, 2, $3,8)$ speaker-oriented illustrates that they relatively conform to the expected request perspectives. For example, in the first situation, around nearly half of the participants made their request hearer-oriented, and around half of the participants made their requests speaker-oriented. Employing speaker-oriented perspective by L2 learners can be viewed as more polite because it avoids naming the hearer as an actor. Blum-Kulka et al. (1989) suggest that focusing on a speaker as an actor can reduce the level of imposition in the request. Under such an interpretation, for example in situation \# 1, the half of participants made their requests speaker-oriented to lower the degree of imposition. Based on the point of view of Blum-Kulka et al., in this situation, if the speaker is emphasized as a primary actor of a borrowing event, the request may be understood as less imposing than the request with a hearer-oriented perspective.

Examining the issue from another perspective (as a function of who will perform the action entailed in the request) proposed by Biesenbach-Lucas (2007), request in the first situation could presuppose a hearer-oriented perspective because the hearer is the primary actor of lending action. This may justify the frequent production of speaker-hearer oriented perspectives in both groups' data. The frequent use of speaker-oriented perspective was only presented in two situations (\# 3 and 5). Such requests can be said to presuppose a speaker-oriented perspective. For example, in situation \# 5 (e.g., assignment extension), even though the professor is the one who grants the extension, the speaker should finish and submit the work.

The analysis of alters indicated that both male and female participants tended to use formal address terms. The fact that the participants were formal might have positive effects on the addressee as the already-established professor/student relationship in Iranian EFL classrooms is formal. Further analysis of the data indicated that half of the requests did not include address terms. Research on cultural and social norms has shown that in the Eastern societies, like Iran and China, social conventions are considered to be very important (Coulmas, 2005). Hence, the avoidance of salutations and address terms might lead Iranian professors to think that L2 students are not polite enough and do not acknowledge their social status as a professor. Hence, Iranian EFL Learners should be aware of the importance of using address terms when mitigating their request.

The results of attention getters, which are in line with Herring (2000), showed the females tended to apologize in a higher percentage. This is rooted in the fact that males have a higher status in Iranian society; therefore, they can fulfill their wishes much more easily than females do. However, the males also employed apology frequently as an attention getter. The frequent use of apology in the males' request production confirms the Brown and Levinson's (1987) claim that males' behavior is sensitive to increased social distance in that they apply more negative politeness strategies (in form of apologies, in this study) to maintain or restore social harmony with those who are more important to them (in the current study, their professor). 
Turning to syntactic downgraders, interrogative and conditional clauses were frequent in the data. Both male and female participants preferred interrogative, whereas the males' preference to use conditional clause was more than the females. Nevertheless, similar to previous studies, the frequencies of past tense and aspectual forms as syntactic modifiers were underrepresented for both males and females (Lundell \& Ehrman, 2012; Woodfield \& Economidou-Kogetsidis, 2010). An explanation to this is that L2 learners may not be aware of the mitigating function of such syntactic downgraders (Woodfield \& Economidou-Kogetsidis, 2010). Furthermore, such linguistic structures may take time to be learnt (Lundell \& Ehrman, 2012).

Turning to specific forms of lexical downgraders in the present study, the results of this study are in line with a number studies that indicated the females utilized please more often than males did (Felix-Brasdefer, 2012; Herring, 2000, 2003; Janssen \& Murachver, 2004). However, the fact that neither the males nor the females used politeness features in high percentage in their requests could be due to the fact that the participants saw the imposition in the request situations as similar. Another possible explanation is that the difference in level of imposition was not enough to trigger differences in the usage of linguistic features of requests. Social power and social distance could be more significant factors to trigger the use of different linguistic devices in requests.

Another possible explanation could be the request form itself does impact the politeness of requests. The interaction between the request form, internal modifiers, and external modifiers also affected the perceived politeness. The degree of (im)politeness of the request is determined by sequence the combination of these pragmalinguistic forms (Fink \& Felix-Brasdefer, 2015). In general, with regard to sociopragmatic awareness and in support of previous research evidence (Bella, 2012; Goy, Zeyrek, \& Otcu, 2012), the participants were seen to underuse lexical phrasal modifiers.

Turning to the external modifiers, similar to previous results in literature (e.g., Woodfield \& Economidou-Kogetsidis, 2010), the most common type of supportive move used by the participants in the request situations was grounder. As explained by Faerch and Kasper (1989), L2 learners prefer to use grounders as the most effective mitigating supportive move because it provides reasons, justifications, and explanations for requests, and thus, "opens an empathetic attitude on the part of the interlocutor in giving his or her insights into the author's underlying motives" (p. 239). For example, in situation \# 1, most of the participants justified their need to borrow a book by explaining that they need to complete the course assignment, and in situation \# 2, the participants stated they might need additional help when studying. These types of elaborations on the part of speakers help hearer understand the speakers' needs better, and thus, might help them to be more receptive to granting the speaker's request.

Another reason may be due to the fact that asymmetrical requests are seen as "involving threat to face" (Economidou-Kogetsidis, 2008, p. 114). Thus, the participants might have resorted to these devices for linguistic and social reasons as ways of demonstrating deference. Only the use of embedding, one of the more complex syntactic modifiers, showed some evidence of development.

\section{Conclusion and implications}

To investigate the differences of paralinguistic features of requests produced by graduate male and female L2 learners' requests, alerters, head acts, and internal and external modifiers were examined. The analyses indicated the participants' preference for the use of conventionally indirect strategies and speaker-hearer oriented perspectives. Further, alerters and politeness marker were underused. In addition, the results of this study indicated that the male and female participants preferred external rather than internal modifiers. Such findings may allow us to suggest that external modifiers are typical features of male and female L2 learners' request production.

The findings of this study can be valuable for future pragmatics studies, which are concerned with L2 learners' performance and pragmatic competence in L2 learning. The findings of the present study also have implications for pragmatics teaching in formal contexts of learning, for course materials and research methodol- 
ogy. L2 learners should use greater internal modifiers, learn that speaker request perspective is less imposing, and use more politeness markers in their requests.

The results can also be beneficial for L2 learners, who can avoid communication breakdowns by having familiarity with the appropriate request strategies that are used in English as foreign context. For example, the cases of fossilization were seen in the data:

$>\quad$ Extract \# 2

- May I take your book?

In the above example, May I take your book is considered negative transfer, which is affected by its Persian equivalence (Mishe Ketabetoon ro begiram).

Another example, which shows using the wrong word choice in their requests, is given below:

$>$ Extract \# 3

- Hello, thank God I saw you here, I was coming to your office for a favor, would you please borrow me the book?

In the above extract of the data, the learner has used borrow wrongly for lend, which can either be due the similarity of their meaning. However, such cases were not frequent in the data, L2 learners still should be reminded to be careful about the selection of words used in their requests. Furthermore, the results of this study provide more insights into how requests can be modified by means of internal and external devices in communication with faculty members. Studies of this kind reveal which parts of a request sequence an L2 learner cannot cope with by specifying its underrepresentation in the realization of that pragmatic feature. The results can raise L2 learners' pragmatic awareness and help them to apply appropriate polite strategies when communicating with a faculty member. Last but not least, educational policy makers responsible for making decisions about educational system can use the results of this study to bring significant changes in the practices of teaching and learning English language by incorporating strategies that improve Iranian L2 learner's pragmatic awareness.

While the present study has indicated a number of trends in the development of request modifiers patterns by graduate male and female Iranian L2 learners, the findings should be considered tentative for a number of reasons. First, the size of the sample population was relatively limited. Thus, further investigations should be done comprising more extensive numbers of L2 learners. Second, the data were collected from university students using a written DCT. The findings may be considered as relating to the knowledge of pragmatically appropriate linguistic behaviors from the specific groups of learners rather than findings from actual conversations (Economidou-Kogetsidis, 2010). With respect to the issue of authenticity, recorded conversations (e.g., Bardovi-Harlig \& Hartford, 2005) can be used to collect natural data. However, because it would be very difficult to gather a substantive number of natural requests from comparable situations and at different levels of social status (Kasper, 2008), it is necessary to apply elicitation tasks. In this study, eight situations were designed. While this is not a small number, future research could add further situations (e.g., cases where requests are addressed to friends in order to determine whether the rank of imposition influences requestive behaviors oriented to friends).

\section{References}

Allami, H. (2006). A sociopragmatic analysis of griping: The case of Iranian students. The Linguistic Journal, $1(1), 59-76$.

Bardovi-Harlig, K., \& Hartford, B. S. (2005). Institutional discourse and interlanguage pragmatics research. In K. Bardovi-Harlig \& B. S. Hartford (Eds.), Interlanguage pragmatics: Exploring institutional talk (pp. 
Rahimi Domakani, M., \& Farhang-Ju, M.

7-36). Mahwah, NJ: Erlbaum. https://doi.org/10.4324/9781410613776

Bella, S. (2012). Pragmatic development in a foreign language: A study of Greek FL requests. Journal of Pragmatics, 44, 1917-1947. https://doi.org/10.1016/j.pragma.2012.08.014

Biesenbach-Lucas, S. (2007). Student writing emails to faculty: An examination of e-politeness among native and non-native speakers of English. Language Learning \& Technology, 11(2), 59-81.

Birjandi, P., \& Rezaie, S. (2010). Developing a multiple-choice discourse completion test of interlanguage pragmatics for Iranian L2 learners. ILI Language Teaching Journal, 6(1), 43-58.

Blum-Kulka, S. (1989). Playing it safe: The role of conventionality in indirectness. In S. Blum-Kulka, J. House, \& G. Kasper (Eds.), Cross-cultural pragmatics: Requests and apologies (pp. 37-70). Norwood: Ablex Publishing.

Blum-Kulka, S., House, J., \& Kasper, G. (1989). The CCSARP coding manual. In S. Blum-Kulka, J. House, \& G. Kasper (Eds.), Cross-cultural pragmatics: Requests and apologies (pp. 273-294). Norwood: Albex Publishing.

Brown, P., \& Levinson, S. (1987). Universals in language usage: Politeness phenomena. Cambridge: Cambridge University Press. https://doi.org/10.1017/CBO9780511813085

Colley, A., \& Todd, Z. (2002). Gender-linked differences in the style and content of e-mails to friends. Journal of Language and Social Psychology, 21(4), 380-392. https://doi.org/10.1177/026192702237955

Coulmas, F. (2005). Sociolinguistics: The study of speakers' choices. Cambridge: Cambridge University Press. https://doi.org/10.1017/CBO9780511815522

Economidou-Kogetsidis, M. (2008). Internal and external mitigation in interlanguage request production: The case of Greek learners of English. Journal of Politeness Research, 4, 111-138. https://doi.org/10.1515/PR.2008.005

Economidou-Kogetsidis, M. (2010). Cross-cultural and situational variation in requesting behavior: Percepts of social situations and strategic usage of request patterns. Journal of Pragmatics, 42, 2262-2281. https://doi.org/10.1016/j.pragma.2010.02.001

Eslami, Z. R., Mirzaei, A., \& Dini, S. (2015). The role of asynchronous computer mediated communication in the instruction and development of EFL learners' pragmatic competence. System, 48, 99-111. https://doi.org/10.1016/j.system.2014.09.008

Faerch, C., \& Kasper, G. (1989). Internal and external modifiers in interlanguage request realization. In S. Blum-Kulka, J. House, \& G. Kasper (Eds.), Cross-cultural pragmatics: Requests and apologies (pp. 221-47). Norwood, NJ: Ablex.

Felix-Brasdefer, C. (2012). E-mail openings and closings: Pragmalinguistic and gender variation in learner-instructor cyber. Discourse and Language Learning across L2 Instructional Settings, 24, 223-248. https://doi.org/10.1163/9789401208598_012

Fink, L. N., \& Felix-Brasdefer, J. C. (2015). Pragmalinguistic variation and Barista perceptions in US café service encounters. In K. Bleeching \& H. Woodfield (Eds.), Researching sociopragmatic variability (pp. 19-48). London: Palgrave Macmillan. https://doi.org/10.1057/9781137373953_2

Goy, E., Zeyrek, D., \& Otcu, B. (2012). Developmental patterns in internal modifiers of requests. In M. Economidou-Kogetisidis \& H. Woodfield (Eds.), Interlanguage request modifiers (pp. 52-85). Amsterdam/Philadelphia: John Benjamins. https://doi.org/10.1075/pbns.217.03goy

Hashemian, M. (2014). A pragmatic study of requestive speech act by Iranian L2 Learners and Canadian native speakers in hotels. Journal of Teaching Language Skills, 33(2), 1-25.

Hashemian, M., \& Farhang-Ju, M. (2017). A pragmatic study of speech acts by Iranian and Spanish English learners. Journal of Research in Applied Linguistics, 8, 14-20.

Herring, S. C. (2000). Gender differences in CMC: Findings and implications. Computer Professionals for Social Responsibility Journal, 18(1). Retrieved from http://cpsr.org/issues/womenintech/herring/

Herring, S. C. (2003). Gender and power in on-line communication. In J. Holmes \& M. Meyerhoff (Eds.), The handbook of language and gender (pp. 202-228). Oxford: Blackwell Publishing. https://doi.org/10.1002/9780470756942.ch9

Hobbs, P. (2003). The medium is the message: Politeness strategies in men's and women's voice mail messages.

12 Consortia Academia Publishing (A partner of Network of Professional Researchers and Educators) 
Journal of Pragmatics, 35(2), 243-262. https://doi.org/10.1016/S0378-2166(02)00100-5

Huffaker, D. A., \& Calvert, S. L. (2005). Gender, identity, and language use in teenage blogs. Journal of Computer-Mediated Communication, 10(2). https://doi.org/10.1111/j.1083-6101.2005.tb00238.x

Jalilifar, A. (2009). Request strategies: Cross-sectional study of Iranian EFL learners and Australian native speakers. English Language Teaching, 2(1), 46-61. https://doi.org/10.5539/elt.v2n1p46

Janssen, A., \& Murachver, T. (2004). The relationship between gender and topic in gender-preferential language use. Written Communication, 21(4), 344-367. https://doi.org/10.1177/0741088304270028

Kasper, G. (2008). Data collection in pragmatics research. In H. Spencer-Oatey (Ed.), Culturally speaking: Culture, communication, and politeness theory (279-303). London: Continuum.

Kasper, G., \& Rose, K. (2002). Pragmatic development in a second language. Malden: Blackwell.

King, B. W., \& Holmes, J. (2014). Gender and pragmatics. The Encyclopedia of Applied Linguistics, 5, 1-6. https://doi.org/10.1002/9781405198431.wbeal1453

Leech, G. N. (2016). Principles of pragmatics. London \& New York: Routledge. https://doi.org/10.4324/9781315835976

Lin, C. Y., Woodfield, H., \& Ren, W. (2012). Compliments in Taiwan and Mainland Chinese: The influence of region and compliment topic. Journal of Pragmatics, 44(11), 1486-502. https://doi.org/10.1016/j.pragma.2012.06.012

LoCastro, V. (2012). Pragmatics for language educators: A sociocultural perspective. New York: Routledge. https://doi.org/10.4324/9780203850947

Lundell, F. F., \& Erman, B. (2012). High level requests: A study of long residency L2 users of English and French and native speakers. Journal of Pragmatics, 44, 756-75. https://doi.org/10.1016/j.pragma.2012.02.010

McConnell-Ginet, S., \& Eckert, P. (2003). Language and gender. Cambridge: Cambridge University Press.

Memari, M., Zia, M., \& Zalpour, A. (2017). An investigation of gender differences between women's and men's informal discussion in Iranian EFL context. Research in Applied Linguistics, 8, 37-42.

Mulac, A., \& Lundell, T. L. (1994). Effects of gender-linked language differences in adults' written discourse: Multivariate tests of language effects. Language \& Communication, 14(3), 299-309. https://doi.org/10.1016/0271-5309(94)90007-8

Mulac, A., Bradac, J. J., \& Gibbons, P. (2001). Empirical support for the gender-as-culture hypothesis: An intercultural analysis of male/female language differences. Human Communication Research, 27(1), 121-152. https://doi.org/10.1093/hcr/27.1.121

Mulac, A., Studley, L. B., \& Blau, S. (1990). The gender-linked language effect in primary and secondary students' impromptu essays. Sex Roles, 23(9-10), 439-470. https://doi.org/10.1007/BF00289762

Pallant, J. (2013). SPSS survival manual. UK: McGraw-Hill Education.

Pishghadam, R., \& Sharafadini, M. (2011). Delving into speech act of suggestion: A case of Iranian EFL learners. International Journal of Business and Social Science, 2(16), 152-160.

Roohani, A., Dayeri, K., \& Farhang-Ju, M. (2017). Role of background knowledge in Iranian L2 learners' reading comprehension test performance. International Journal of Language Testing, 7(1), 28-39.

Rose, K. (2009). Interlanguage pragmatic development in Hong Kong: Phase 2. Journal of Pragmatics, 41(11), 2345-2364. https://doi.org/10.1016/j.pragma.2009.04.002

Rubin, D. L., \& Greene, K. (1992). Gender-typical style in written language. Research in the Teaching of English, 26(1), 7-40.

Saidi, M., \& Khosravi, M. (2015). EFL learners' perceptions of (im)politeness: The possible gender differences. International Journal of Language and Applied Linguistics, 1(1), 1-11.

Saito, J. (2010). Managing confrontational situations: Japanese male superiors' interactional styles in directive discourse in the workplace. Journal of Pragmatics, 43(6), 1689-1706. https://doi.org/10.1016/j.pragma.2010.11.008

Scollon, R., \& Scollon, S. W. (2001). Intercultural communication. Malden: Blackwell Publishing.

Searle, J. R. (1969). Speech acts: An essay in the philosophy of language. Cambridge: Cambridge university press. https://doi.org/10.1017/CBO9781139173438 
Rahimi Domakani, M., \& Farhang-Ju, M.

Shams, R., \& Afghari, A. (2011). Effects of culture and gender in comprehension of speech acts of indirect request. English Language Teaching, 4, 279-287. https://doi.org/10.5539/elt.v4n4p279

Speer, S. A. (2002). Natural and contrived data: A sustainable distinction. Discourse Studies, 4(4), 511-525. https://doi.org/10.1177/14614456020040040601

van Dijk, T. A., Ting-Toomey, S., Smitherman, G., \& Troutman, D. (1997). Discourse, ethnicity, culture, and racism. In T. A. van Dijk (Ed.), Discourse as social action (pp. 144-177). Sage Publications: London.

Woodfield, H., \& Economidou-Kogetisidis, M. (2010). I just need more time: A study of native and non-native requests to faculty for an extension. Multilingua, 29(1), 77-118. https://doi.org/10.1515/mult.2010.004

14 Consortia Academia Publishing (A partner of Network of Professional Researchers and Educators) 